\title{
The phylogenetic position and ultrastructure of the uncultured bacterium Achromatium oxaliferum
}

\author{
Ian M. Head, ${ }^{1}$ Neil D. Gray, ${ }^{1}$ Ken J. Clarke, ${ }^{2}$ Roger W. Pickup ${ }^{2}$ \\ and J. Gwynfryn Jones ${ }^{3}$
}

Author for correspondence: Ian M. Head. Tel: +44191222 7024. Fax: +44 1912225431.

e-mail: i.m.head@newcastle.ac.uk

1 Newcastle Research Group in Fossil Fuels and Environmental Geochemistry, Drummond Building, University of Newcastle upon Tyne, Newcastle upon Tyne NE1 7RU, UK

2 Institute of Freshwater Ecology, Windermere Laboratory, Ambleside, Cumbria LA22 OLP, UK

3 Freshwater Biological Association, Windermere Laboratory, Ambleside, Cumbria LA22 OLP, UK
Achromatium oxaliferum is a large, morphologically conspicuous, sedimentdweiling bacterium. Nothing is known concerning its phylogeny and it has eluded all attempts at laboratory cultivation. The limited physiological description of A. oxaliferum has been based on morphological features of the bacterium such as the presence of intracellular sulphur inclusions. $A$. oxaliferum cells were purified from a wetland region close to Rydal Water (Cumbria, UK). Scanning and transmission electron microscopy revealed that a number of morphologically distinct $A$. oxaliferum cell-types, based on cell surface features and the size and abundance of calcite and sulphur inclusions within the cells, were present in a single sample of purified cells. PCR was used to amplify almost full-length 165 rRNA gene sequences from DNA extracted from A. oxaliferum cells directly purified from sediments. The PCR products were cloned and partial sequences (approx. $400 \mathrm{bp}$ ) were determined for seven of the clones. Three different sequence clusters were recovered from the clone libraries. A near full-length (1489 bp) 165 rRNA gene sequence was determined for a representative clone of the most dominant sequence-type (52\% of the sequences). Comparative sequence analysis showed A. oxaliferum to form a deep branching lineage within the $\gamma$-subdivision of the Proteobacteria. A. oxaliferum was related most closely to the Chromatium assemblage that includes sulphur-oxidizing symbiotic bacteria, purple sulphur bacteria, and sulpur- and iron-oxidizing thiobacilli. Phylogenetic inferences made using distance, parsimony and maximum likelihood methods all placed $A$. oxaliferum with this group of bacteria. Bootstrap support for a relationship with any particular lineage within the assemblage was weak. The seven clone sequences recovered from the $A$. oxaliferum cells however formed a monophyletic group well supported by bootstrap analysis (85-100\% support depending on the analysis done). It was concluded that $A$. oxaliferum was related to organisms of the Chromatium assemblage but constituted a novel lineage within this group of bacteria. A. oxaliferum cells were confirmed as the source of the 165 rRNA sequence obtained, by the use of a fluorescently-labelled 165 rRNAtargeted oligonucleotide specific for the $A$. oxaliferum rRNA sequence.

Keywords: Achromatium oxaliferum, uncultured bacteria, 165 rRNA, molecular microbial ecology

Abbreviations: EDX, energy dispersive X-ray microanalysis; RDP, Ribosomal Database Project; SEM, scanning electron microscopy; SIM, single ion monitoring; TEM, transmission electron microscopy.

The GenBank accession numbers for the seven sequences determined in this work are L42543 and L48222-L48227. 


\section{INTRODUCTION}

Achromatium oxaliferum was first described over a century ago (Schewiakoff, 1893) yet knowledge of its phylogeny, physiology and ecology remains scant. The bacterium is unusualiy large, ranging in width from $5 \mu \mathrm{m}$ to $40 \mu \mathrm{m}$ and from $15 \mu \mathrm{m}$ to mote than $100 \mu \mathrm{m}$ in length. A. oxaliferum cells contain characteristic inclusions of sulphur and calcium carbonate. The identity of the calcium carbonate inclusions has been inferred largely by their dissolution with dilute acid (La Riviere \& Schmidt, 1989, 1991), but the inclusions have recently been confirmed as being crystalline calcite using spectroscopic techniques (Head $e t$ al., 1995). The presence of sulphur inclusions within $A$. oxaliferum cells has been used to imply that the organism is a sulphide-oxidizing lithotroph, though no direct evidence has been obtained. The role of the calcite likewise has not been elucidated though several workers have speculated that it may be involved in buoyancy regulation and chemotaxis (Babenzien, 1991, 1992), buffering of $\mathrm{pH}$ (La Riviere \& Schmidt, 1991) or maintaining a high intracellular partial pressure of $\mathrm{CO}_{2}$ to aid inorganic carbon fixation (Head et al., 1995).

A. oxaliferum has been observed in a diverse range of saline and freshwater sediments (e.g. Gicklhorn, 1920; Nadson \& Visloukh, 1923; Skuja, 1948; Starr \& Skerman, 1965) and is apparentiy widespread and locally abundant. An understanding of the bacterium and its role in sediments has been hampered by an inability to cultivate the organism in the laboratory. At present, only ecophysiological inferences based on the bacterium's habitat and its behaviour in relation to its environment can be made. Ultimately it will require cultivation of the organism to reveal its true physiology. However, the introduction of small-subunit rRNA sequence analysis to infer the phylogeny of micro-organisms has provided an opportunity to understand the evolutionary relationships between micro-organisms even if they cannot be cultivated in the laboratory (Amann et al., 1995; Ward et al., 1992). A. oxaliferum is an ideal candidate for application of this approach. It is morphologically conspicuous, readily puriffed from natural samples and cannot be cultivated in the laboratory.

The taxonomy of A. oxaliferum is at present unclear and Acbromatium spp. are currently classified as non-photosynthetic, non-fruiting, gliding bacteria as a genus incertae sedis, though it has been stated that 'pending pure culture studies any classification can only be provisional' (La Riviere \& Schmidt, 1989). We have adopted molecular biological methods to elucidate the classification of $A$. oxalifertm, to circumvent the requirement for pure cultures of the bacterium.

The aim of this study was to use the rRNA approach as an aid to understanding the phylogeny of $A$. oxaliferum and to provide tools for studying the diversity and dynamics of natural populations of this bacterium using fluorescent whole-cell hybridization techniques and PCR (Amann et al., 1995; Ward et al., 1992). When allied with traditional microbial ecology, these techniques can substantially improve our understanding of the biogeochemical role of uncultivated bacteria.

\section{METHODS}

Sampling site, enumeration and purification of cells from sediment. A number of sites in the North of England that held populations of $A$. oxaliferum were identified. A wetland area dominated by willow and emerging reeds close to Rydal Water (OS grid teference NY 351065) was found to contain the highest populations of the bacterium. This site was used as a source of A. oxaliferum celis for the present study. To obtain bulk samples of A. oxaliferum cells a hand-operated vacuum sampler was used to remove surface sediment from the sampling site (Pickup, 1995). This provided sediment containing $10^{6}-10^{7}$ cells ml ${ }^{-1}$ and $100-200 \mathrm{ml}$ samples were processed when purifying cells for DNA extraction. Sediments were initially screened through a $64 \mu \mathrm{m}$ nylon mesh to remove larger sediment particles and the cells were subsequently purified using the method of de Boer $e t$ al. (1971). Crude preparations of purified cells were used for electron microscopy and whole-cell hybridization. Cells that were used for extraction of DNA were washed exhaustively (usually four or five times) in sterile distilled water until preparations free of contaminating smaller bacteria (determined by acridine orange staining) were obtained.

Depth profiles of A. oxaliferum populations were determined in sediment cores obtained using a modified $25 \mathrm{ml}$ polypropylene syringe. The core was sectioned at $3 \mathrm{~mm}$ intervais and the core sections were fixed with formaldehyde $(2 \%, \mathrm{v} / \mathrm{v}$, final concentration). A. oxaliferum cells were counted using a Sedgwick Rafter cell (Jones, 1979).

Membrane inlet mass spectroscopy (MIMS). Depth profiles of pore water gases were determined in sediment cores obtained using a modified $25 \mathrm{ml}$ polypropylene sytinge. The cores were returned to the laboratory, where depth profiles of dissolved gases were obtained using MIMS (Lloyd et al., 1986). The MIMS probe was constructed from a length of unphased fused silica gas chromatography (GC) column (1.5 m long, $0.5 \mathrm{~mm}$ i.d.) linked to the mass spectrometer (MS) interface of a Fisons Trio 1000 GC-MS. A silicon rubber membrane (Silastic, Dupont) approximately $100 \mu \mathrm{m}$ thick was gently stretched over the open end of the column. The membrane was further secured by cementing with more silicon rubber. Measurements of dissolved gases at a resolution greater than $1 \mathrm{~mm}$ could be made by careful insertion of the probe into sediment cores using a micromanipulator. The probe was allowed to equilibrate for at least $30 \mathrm{~min}$ at each depth. Measurements of dissolved oxygen $\left(\mathrm{O}_{2}\right)$ were made using single ion monitoring (SIM) at mass 32 . The probe was calibrated using air-saturated water at $25^{\circ} \mathrm{C}$ (258 $\mu \mathrm{mol} \mathrm{O} \mathrm{O}^{-1}$ : American Public Health Association, 1980) and water sparged with helium $\left(0 \mu \mathrm{mol} \mathrm{O}_{2} \mathrm{~L}^{-1}\right)$. Immediately after oxygen profiles were taken cores were sectioned in $3 \mathrm{~mm}$ increments and cell counts conducted on the core sections.

\section{Electron microscopy (EM)}

SEM. An air-brush with a size-adjusted vent aperture was used to spray a suspension of the purified cells onto the polished, frostfree surface of a brass block cooled to $-196{ }^{\circ} \mathrm{C}$ with liquid nitrogen. Physical fixation of the cells by rapid freezing was achieved by this means; cells in immediate contact with the cooled block surface were fixed in a natural condition, whereas cells contacting previously sprayed layers cooled more slowly, their cell walls shrinking back to reveal the sub-surface features beneath. 
For examination of whole cells, frozen material was collected from the cold block surface and freeze-dried. For examination of cell internal structure, frozen material was collected and cells broken by grinding at $-196{ }^{\circ} \mathrm{C}$ in a $5 \mathrm{ml}$ glazed ceramic crucible using a smooth glass rod. The resulting paste of frozen broken cells was collected and freeze-dried. All freeze-dried samples were mounted onto specimen support stubs and sputter-coated with gold before SEM examination.

Energy-dispersive X-ray microanalysis (EDX) (Link Isis, Oxford Instruments) with SEM was used to qualitatively examine inclusions in $A$, oxalifertm prepared by the freeze-fixation method described above; the mounted samples were coated with carbon rather than gold before examination.

TEM. Concentrated and cleaned cells were fixed in $2 \%(\mathrm{v} / \mathrm{v})$ glutaraldehyde $(60 \mathrm{~min})$ followed by $2 \%$ (w/v) osmium tetroxide ( $30 \mathrm{~min}$ ), both made up in filtered water from the sample collection site buffered with $0.1 \mathrm{M}$ sodium cacodylate. The glutaraldehyde primary fixative was buffered at $\mathrm{pH}$ 6.8. Cells were then washed in distilled water. For cell surface examination, droplets of fixed material were placed onto Formvarcoated grids and shadowed with chromium. For ultra-microtomy, fixed cells were dehydrated through an increasing concentration series of ethanol in water $(30 \%$ to $100 \%, v / v)$ and embedded in Spurr resin. Ultra-thin sections mounted on grids were triple stained in lead citrate/uranyl acetate/lead citrate each at $2 \%(\mathrm{w} / \mathrm{v})$ in aqueous solutions.

All electron microscope examinations were carried out using a JEOL JEM100CX Temscan electron microscope.

DNA extraction. Purified $A$. oxaliferum cells $\left(10^{7} 10^{8}\right)$ in a $1.5 \mathrm{ml}$ microcentrifuge tube were washed three times in $1 \mathrm{ml}$ sterile TE buffer (10 mM Tris/HCl, $1 \mathrm{mM}$ EDTA, $\mathrm{pH} 8.0$ ) and resuspended in $0-1 \mathrm{ml} \mathrm{TE}$. TE buffer containing $3 \%(\mathrm{w} / \mathrm{v})$ SDS $(0.2 \mathrm{ml})$ was added to the cells and the tube was vortexed for $3 \mathrm{~min}$. 'The cell lysate was extracted three times with $0.6 \mathrm{ml} \mathrm{TE}$ buffered phenol and three times with chloroform. The aqueous phase was transferred to a fresh microcentrifuge tube and 2 vols ice-cold absolute ethanol added. The DNA was precipitated overnight at $-20^{\circ} \mathrm{C}$ and pelleted by centrifugation (13000 r.p.m., $10 \mathrm{~min}$, MSE Microcentaur). The DNA was redissolved in $50 \mu$ sterile TE buffer and used directly in PCR reactions. DN $\Lambda$ preparations typically contained $20-40 \mathrm{ng}$ DNA $\mu l^{-1}$ with an $A_{260} / A_{280}$ of $1 \cdot 5-1 \cdot 8$.

Amplification, cloning and sequencing of 165 rRNA genes. Almost full-length $16 \mathrm{~S}$ rRNA genes were amplified using primers $\mathrm{pA}$ and $\mathrm{pH}^{\prime}$ (Edwards et al., 1989) and PCR reaction conditions as described by Embley (1991) except that Dynazyme DNA polymerase (Flowgen) was used. Prior to cloning, PCR products were purified using the SpinBind system (Flowgen). The PCR products were cloned using the pGEM-T vector (Promega) with Escherichia coli JM109 as host (high-efficiency competent cells; Promega). Cloning procedures were carried out in accordance with the supplier's instructions. Ten positive clones were selected at random from the library and cultivated in LB broth ( $10 \mathrm{ml}$ ) containing ampicillin ( $50 \mathrm{mg} \mathrm{l}^{-1}$ ). A sample of overnight culture $(1.5 \mathrm{ml})$ was used to purify plasmid DNA using a Prep-A-Gene plasmid purification kit (Bio-Rad). The presence of an insert of the correct size (about $1.75 \mathrm{~kb}$ including flanking plasmid DNA) in the plasmids was determined by electrophoresis, following PCR amplification using pUC/M13 forward and reverse sequencing primers to amplify the insert. Seven of the ten plasmids contained inserts of the appropriate size.
The DNA inserts were amplified using pUC/M13 sequencing primers; the PCR products were purified using SpinBind cartridges and sequenced using a DyeDeoxy cycle sequencing kit and an ABI 373A automated DNA sequencer (Applied Biosystems). The sequencing primers used were those of Edwards et al. (1989). An additional sequencing primer (Aox859f: 5'-TAGCTAACGCGATAAGTCAA-3', positions 859878 , E. coli numbering) was also used to confirm sequence data associated with the presence of an unusual secondary structure feature present in the inferred rRNA sequence.

Phylogenetic analyses. The rRNA sequences were aligned manually with all the sequences present in the RDP alignment of prokaryotic small-subunit rRNA sequences (Maidak et al., 1994) using the GDE sequence editor, and corrected for known secondary structure features (Gutell et al., 1994). A subset of 98 sequences representing the $\alpha$-, $\beta$-, $\gamma$ - and $\delta$-subdivisions of the Proteobacteria was extracted from the original alignment and used for initial phylogenetic analyses. More detailed phylogenetic analyses were carried out using sequences from representative members of the Cbromatium assemblage of the $\gamma$ Proteobacteria. In addition to the RDP sequences, scquence data for the iron-oxidizing phototroph, strain L7 (Ehrenreich \& Widdel, 1994; X78718), the bacterial ectosymbiont of the marine nematode Laxus sp. (Polz et al., 1994; U14727) and Nitrococcus mobilis (Teske et al., 1994; L35510) were obtained from GenBank. Distance analyses using the Jukes \& Cantor (1969) correction were done using the DNADIST program and trees generated from distance matrices using the neighbourjoining method (Saitou \& Nei, 1987). Parsimony analyses were done using the DNAPARS program and maximum likelihood (Felsenstein, 1981) analyses wete done using fastDNAmi (Olsen $e t$ al., 1994). Sequence data for distance mattix and parsimony analyses were subjected to bootstrap resampling (data resampled 100 times) using the SEQBOOT program and consensus trees generated using the CONSENSE program. All software used, except fastDNAml, was from the PHYLIP package (Felsenstein, 1989). The CHECK_CHIMERA program (Maidak et al., 1994) was used to determine if a possible chimeric sequence had been generated during the PCR. In analyses of the near complete sequence from clone 5, positions 87-1350 (E. coli numbering) were employed. Analyses of the partial sequences used positions 119-494 (E. coli numbering).

Whole-cell hybridization. Three volumes of freshly made paraformaldehyde solution $(4 \%, \mathrm{w} / \mathrm{v}$, in sterile distilled water) were added to a crudely purified suspension $(0.2 \mathrm{ml})$ of $A$. oxaliferum cells and the suspension was incubated at $4{ }^{\circ} \mathrm{C}$ overnight. The cells were washed in PBS $(130 \mathrm{mM} \mathrm{NaCl}$, $10 \mathrm{mM}$ sodium phosphate, $\mathrm{pH} 7 \cdot 4$ ), pelleted and treated with $1 \mathrm{M} \mathrm{HCl}$ for $10 \mathrm{~min}$ (MacNaughton et al., 1994) to remove intracellular calcite that caused high levels of non-specific binding of fluorescently labelled oligonucleotides. The cells were pelleted once more (13000 r.p.m., 2 min, MSE Microcentaur) and resuspended in $50 \%$ ethanol. Fixed cells were used immediately or stored at $-20^{\circ} \mathrm{C}$.

Whole-cell hybridization was carried out in liquid phase as $A$. axaliferum cells were readily removed from gelatin-coated slides during the wash procedures. A suspension of fixed cells containing $10^{5} 10^{6}$ cells was added to a sterile $1.5 \mathrm{ml}$ microcentrifuge tube. The $A$. oxaliferum cells were allowed to settle and the supernatant was removed. Hybridization buffer $(38 \mu 1$; Amann et al., 1990a) and fluorescently labelled oligonucleotide ( $2 \mu \mathrm{l}$ of a $50 \mathrm{ng} \mathrm{m}^{-1}$ solution) were added to the cells. The tube was incubated at $37,45,55,65$ or $75^{\circ} \mathrm{C}$ for $3 \mathrm{~h}$ and the hybridized cells were washed with hybridization buffer $(3 \times$ $0 \cdot 1 \mathrm{ml}$ ) at the hybridization temperature. The cells were pelleted 
(13000 r.p.m.,2 min, MSEMicrocentaur)andresuspendedin Citifluor (Citifluor Ltd) prior to mounting on a slide. The hybridized cells were viewed using an Olympus BH-2-RFCA microscope fitted with a high-pressure mercury vapour lamp and blue and green filter sets (BP545, BP490). Micrographs were taken using Kodak Ektachrome 200 film. Phase-contrast and bright-field micrographs were taken using automatic exposure and an exposure time of $10 \mathrm{~s}$ was used for fluorescence micrographs.

The following probes were used for fluorescent whole cell hybridization: Fub338 (5'-GCTGCCTCCCGTAGGAGT-3', positions 338-355 E. coli numbering), nonEub (5'-ACTCCTACGGGAGGCAGC-3', positions 355-338 E. coli numbering), Aox466 (5'-TCAAGA'T'TAGCTGATA T-3', positions 466482, E. coli numbering) and Aox655 (5'-ACCCCCCTCTCTCGTACT-3', positions 655-672 E. coli numbering). HPLCpurified probes were supplied commercially (Genosys Europe). All probes were labelled with tetramethylthodamine. All $A$. oxaliferam-specific probe sequences were screened against the complete GenBank and EMBL databases using Fast A (Pearson, 1990 ) and the RDP database using the CHECK_pROBE program (Maidak et al., 1994). No matching sequences were found.

\section{RESULTS}

\section{Abundance and distribution of $A$. oxaliferum in sediments}

In sediments from the Rydal Water site, A. oxaliferum was an abundant member of the bacterial population (Fig. 1); it was shown previously to constitute more than $90 \%$ of the bacterial biovolume in sediments where it occurs (Head et al., 1995). Populations of A. oxaliferum can teach levels greater than $10^{4}-10^{5}$ cells per $\mathrm{cm}^{3}$ of sediment (Fig. 1). They generally occupy only the upper few centimetres of the sediment, with a population maximum at $3-9 \mathrm{~mm}$ below the sediment sutface, and they persist in the sediments throughout the year. The population maximum occurred as dissolved oxygen was depleted and considerable numbers persisted at depths where dissolved oxygen was no longer detectable (Fig. 1).

\section{Morphology and ultrastructure of $A$. oxaliferum cells}

Standard EM chemical fixation and embedding protocols dissolved and extracted the inciusions within the $A$. oxaliferum cell. Physical fixation for SEM carried out by rapid spray-freezing enabled the natural cell shape of $A$. oxaliferum to be preserved with minimal shrinkage and loss of intracellular inclusions. Scanning electron micrographs showed typical cells with inclusions just visibie beneath the cell surface (Fig. 2a) and cell-surface structures (Fig. 2b). Fixation by spray-freezing, followed by freezegrinding and drying, also enabled the location and arrangement of these inclusions to be examined. Transversely and longitudinally fractured cells showed a highly regular arrangement of the calcite inclusions atound the periphery of the cell (Fig. 2c, d). The shape of the calcite inclusions indicated an arrangement of differently shaped

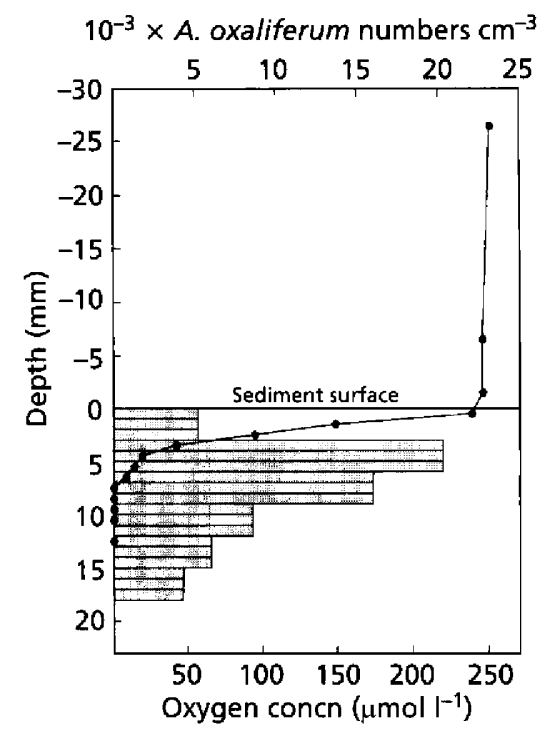

Fig. 1. Depth distribution of $A$. oxaliferum cells (bars) and dissolved oxygen (O) in sediment core from Rydal Water.

crystals in a highly ordered array resembling stones in an arch, although minimal shrinkage of the cells during preparation may have accentuated the effect. The inclusions in the centre of the cell were smaller, spherical and did not appear to be as ordered as the peripheral calcite inclusions. This organization of the inclusions was confirmed in Nile Red stained preparations of unfixed whole cells that were optically sectioned using a confocal scanning laser microscope (data not shown). The small sulphur droplets were more evenly distributed throughout the cell. The presence of sulphur was confirmed by EDX/SEM as occurring in the small inclusions preserved in frozen material. In both sectioned and frozen material, calcite inclusions were typically $5 \cdot 0-6.0 \mu \mathrm{m}$ in size; sulphur inclusions measured $0.5-2 \cdot 0 \mu \mathrm{m}$. This was consistent with measurements made by light microscopy (Babenzien, 1991).

By reducing the rate of spray-freezing (loweting the cooling rate) during physical fixation of the cells, the cell volume was decreased by approximately $50 \%$, condensing the cytoplasm and shrinking back the cell envelope to reveal the size, shape and distribution of the near-surface cellular inclusions (Fig. $3 \mathrm{a}-\mathrm{c}$ ).

The size and distribution of intraceliular inclusions revealed by this methodology demonstrated the presence of a number of morphotypes of $A$. oxaliferum cells in a single sample (Fig. 3a-c). In addition 'rough' (Fig. 2b) and 'smooth' (Fig. 2a) cells were observed in rapidiy spray-frozen samples. The rough surface of some cells was believed to be equivalent to the filaments observed in sectioned and shadow-cast preparations. It was noted previously that if cells were washed and centrifuged during preparation for EM examination then no slime layers or filaments were observed on any of the cells (de Boer et al., 1971). Our samples were never treated in this manner and cells with either a complete covering of 

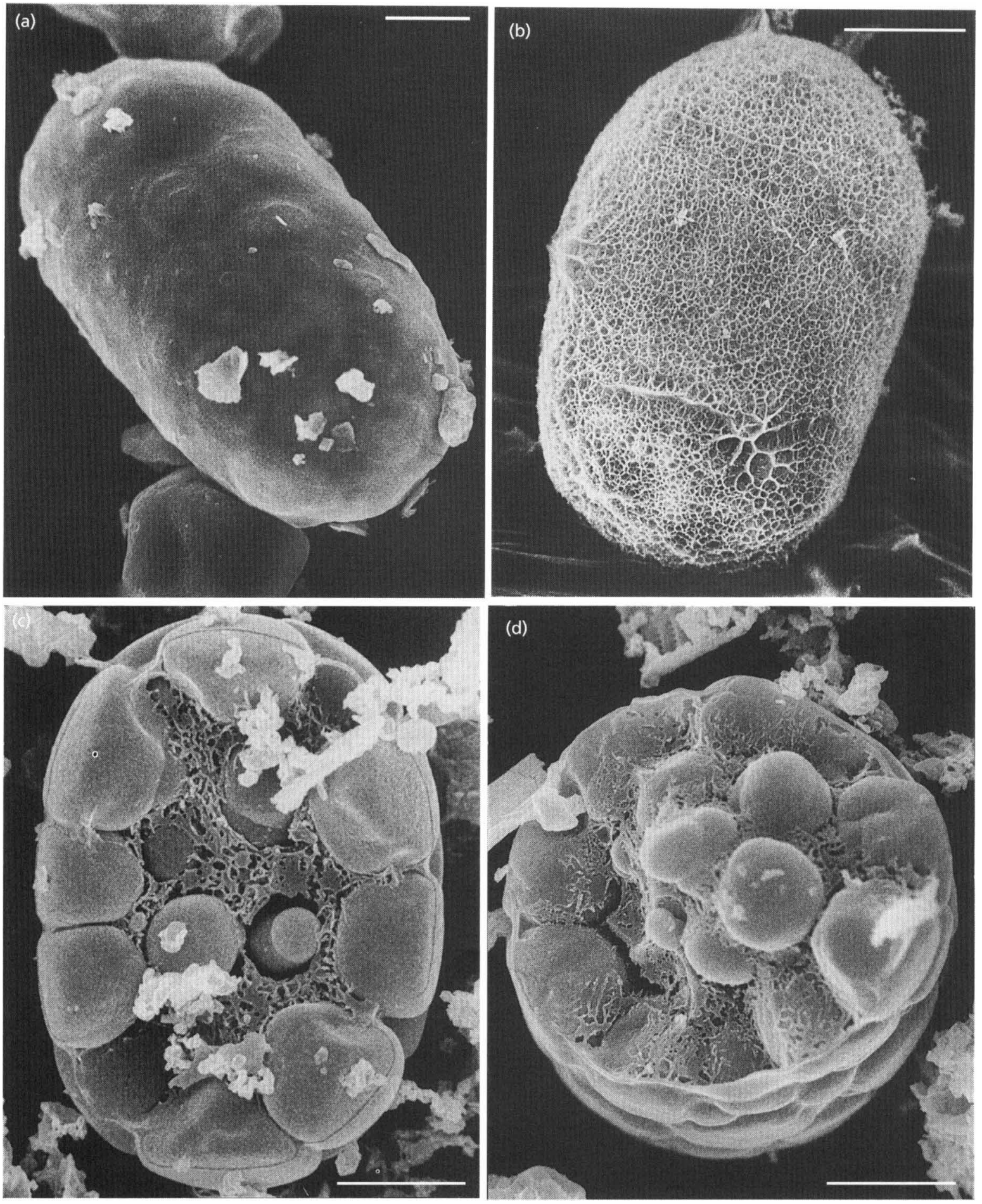

Fig. 2. Scanning electron micrographs of spray-frozen $A$. oxaliferum cells. (a) Whole cell of the 'smooth' surface type; cell inclusions are just visible below the surface. (b) Whole cell of the 'rough' surface type. The pitted appearance of the mucilaginous cell covering is due to removal of small ice crystals during preparation. (c) Longitudinally fractured whole cell showing the arrangement of calcite crystals around the cell perimeter. The small spherical inclusion on the right contains sulphur. (d) Transverse section of a typical cell. Bars, $5.0 \mu \mathrm{m}$ 

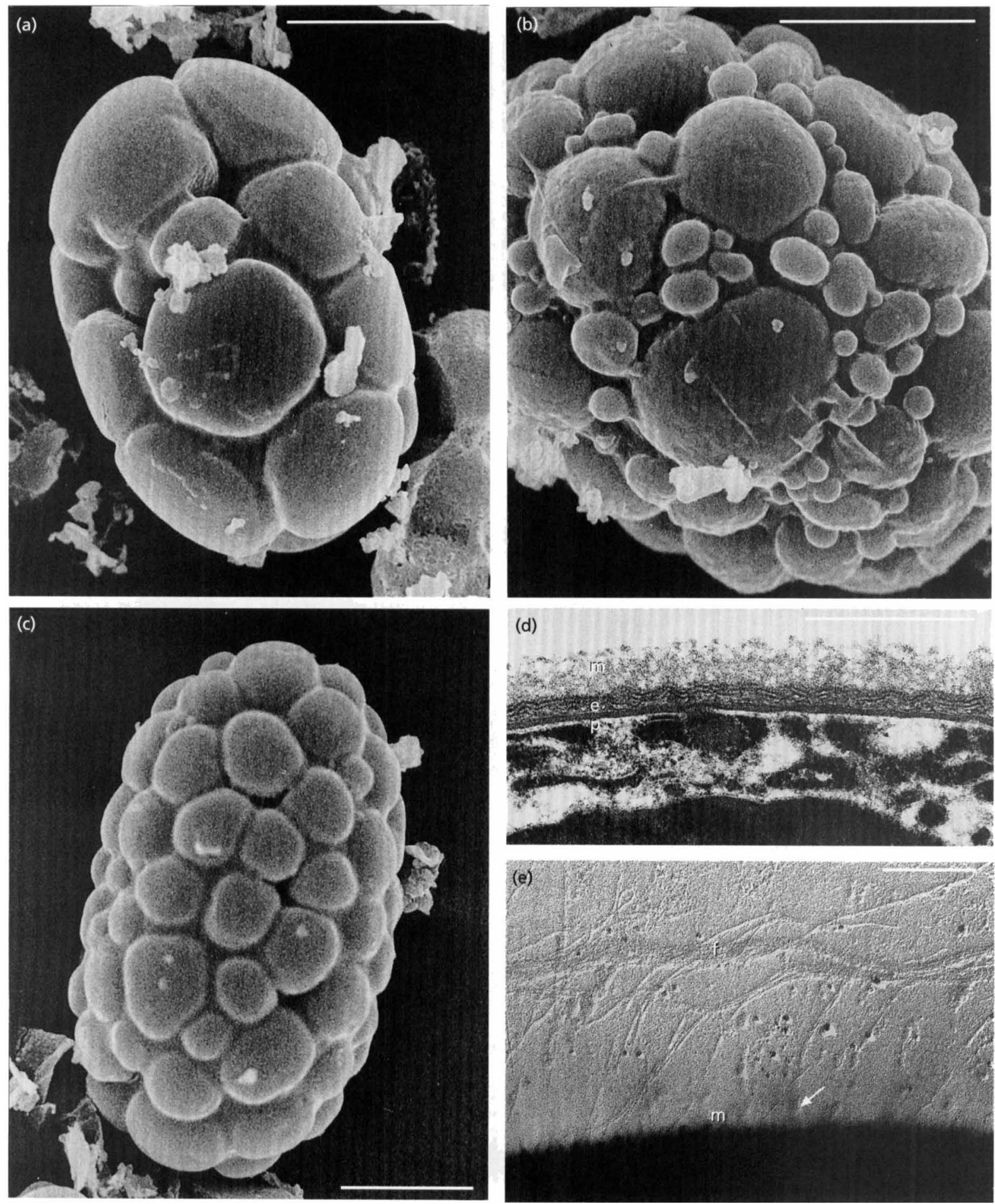

Fig. 3. Scanning and transmission electron micrographs of $A$. oxaliferum cells. (a-c) Spray-frozen preparations of three morphotypes of cells with a 'smooth' surface: (a) cell with large intracellular calcite inclusions (SEM); (b) cell with small sulphur inclusions dispersed among the calcite inclusions (SEM); (c) cell containing regularly sized calcite inclusions (SEM); (d) thin section through cell surface showing Gram-negative structure (TEM): m, mucilage; e, envelope; p, plasmalemma. (e) Shadow-cast preparation of cell surface showing filaments ( $f$ ) projecting through the mucilage layer ( $m$ ) of a 'rough'surfaced cell. The arrow indicates dense inclusions in the mucilage. Bars, $5.0 \mu \mathrm{m}(\mathrm{a}-\mathrm{c}) ; 0.5 \mu \mathrm{m}(\mathrm{d}-\mathrm{e})$. 
Table 1. Whole-cell hybridization with fluorescent oligonucleotide probes

++ , Strong hybridization signal equivalent to fluorescence with Eub338 at $45^{\circ} \mathrm{C}$; + , intermediate fluorescence, betwcen that of Eub338 at $45^{\circ} \mathrm{C}$ and non Eub at $45^{\circ} \mathrm{C}$; - , fluorescence no greater than negative control probe nonEub hybridized at $45^{\circ} \mathrm{C}$. ND, Not done.

\begin{tabular}{|c|c|c|c|c|c|c|c|c|c|c|c|c|c|c|c|c|c|c|c|c|c|c|c|c|}
\hline \multirow[b]{2}{*}{ Temp. $\left({ }^{\circ} \mathrm{C}\right) \ldots$} & \multicolumn{6}{|c|}{ Eub338 } & \multicolumn{6}{|c|}{ Aox 655} & \multicolumn{6}{|c|}{ Aox466 } & \multicolumn{6}{|c|}{ nonEub } \\
\hline & 30 & .37 & 45 & 55 & 65 & 75 & 30 & 37 & 45 & 55 & 65 & 75 & 30 & 37 & 45 & 55 & 65 & 75 & 30 & 37 & 45 & 55 & 65 & 75 \\
\hline 4. axaliferum & ND & ++ & ++ & ++ & + & - & ++ & $+t$ & +- & ++ & - & - & + & - & - & - & $\therefore 0$ & $x_{0}$ & + & - & & NI) & vi & $\therefore D$ \\
\hline P. putida $\mathrm{PaW} 1$ & $\mathrm{ND}$ & $\mathrm{ND}$ & ++ & ++ & - & $\therefore \mathrm{N}$ & ++ & ++ & ++ & - & - & $\mathrm{No}$ & No & $\mathrm{ND}$ & - & - & $\therefore$ & ND & + & ... & - & $\therefore 0$ & N13 & is \\
\hline
\end{tabular}
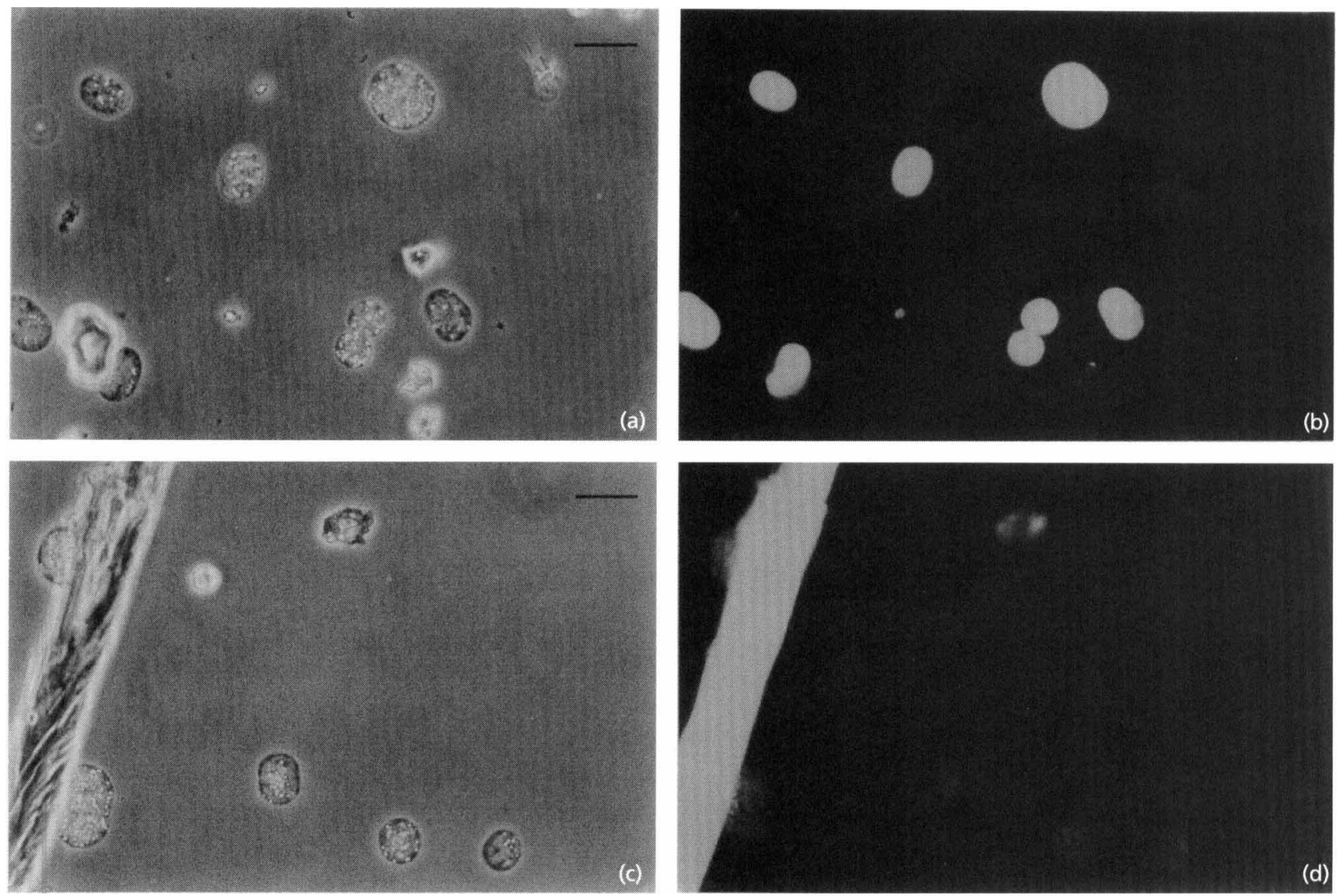

Fig. 4. Whole-cell hybridization of $A$. oxaliferum cells with tetramethyl rhodamine labelled oligonucleotide probes. (a, $c)$ Phase-contrast micrographs; ( $b, d)$ epifluorescence micrographs of the same fields. $(a, b)$ The $A$. oxaliferum cells were hybridized with the $A$. oxaliferum-specific probe Aox655 and showed strong fluorescence. (c, d) The A. oxaliferum cells were hybridized with the negative control probe nonEub and show only weak fluorescence. The presence of rRNA complementary to probe Aox655 indicates that the rRNA sequence obtained from the clone library came from $A$. oxaliferum cells. Bars, $20 \mu \mathrm{m}$.

filaments (rough) or no filaments (smooth) were observed in a single sample.

TEM showed the cell envelope structure to be typical for a Gram-negative bacterium, and was consistent with previous results (de Boer et al., 1971). The cytoplasm was enclosed by a plasma-membrane surrounded by a diffuse layer of periplasmic gel through which tan a dense peptidoglycan layer. $A$ further membrane surrounded the whole and the combined structure measured $0.1 \mu \mathrm{m}$ in thickness (Fig. 3d).

In 'smooth'-surfaced cells a slime layer measuring $0.1 \mu \mathrm{m}$ in thickness was present around the cell envelope whereas in many other cells this layer was thicker but more diffuse. The thicker mucilage layer was resolved in more detail by shadow-cast preparations (Fig. 3e), where it was found to measure approximately $1.5 \mu \mathrm{m}$ in thickness and to contain 


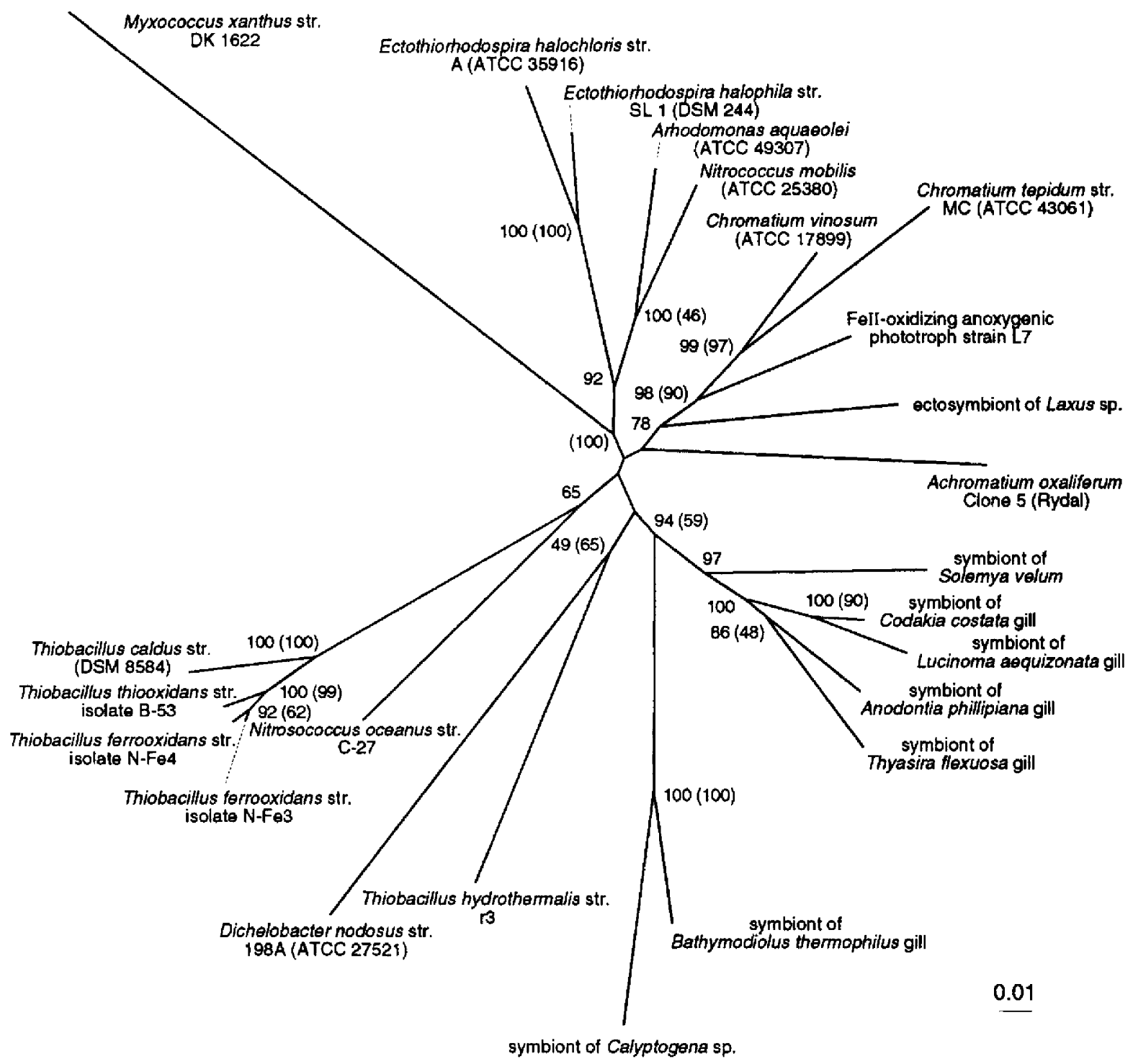

Fig. 5. Distance tree generated from an alignment of 1265 positions of the $A$. oxaliferum 165 rRNA sequence from clone 5 of the Rydal Water 165 rRNA clone library and representatives of the Chromatium assemblage. Myxococcus xanthus was used as an outgroup. Bootstrap values greater than $40 \%$ are shown at nodes; bootstrap values from distance analyses are shown with values from parsimony analysis in parentheses.

small denser areas throughout its depth (Fig. 3e). Similar observations were made by de Boer et al. (1971), who interpreted these structures as vesicles associated with the filaments. In a number of cells the slime layer was penetrated by a dense integument of fine filaments measuring between 3.0 and $3.5 \mu \mathrm{m}$ in length (Fig. 4e). These were also noted in the work of de Boer et al. (1971) and suggested to be involved in the motility of the bacterium.

\section{Phylogeny of $A$. oxaliferum}

PCR was used to amplify $16 \mathrm{~S}$ rRNA genes from $A$. oxaliferum cells directly purified from sediment. Initial attempts to sequence the PCR product directly amplified from purified samples of $A$. oxaliferum resulted in poorquality sequence data with a high proportion of ambiguous bases. Therefore the PCR product was cloned and inserts from a selection of individual clones were sequenced. A near full-length sequence (1489 bp) was determined for one of the clones (clone 5).

Evidence that the full-length 165 rDNA sequence was not chimeric. The CHECK_CHIMERA program suggested a possible chimera with a break at position 270 of the $A$. oxaliferum-derived sequence in clone 5 . The $S_{\mathrm{ab}}$ values (reported in the output from the CHECK_CHIMERA program) obtained by comparison with the most closely related sequences in the RDP database were generally below 0.6 and many of the sequences reported by the 


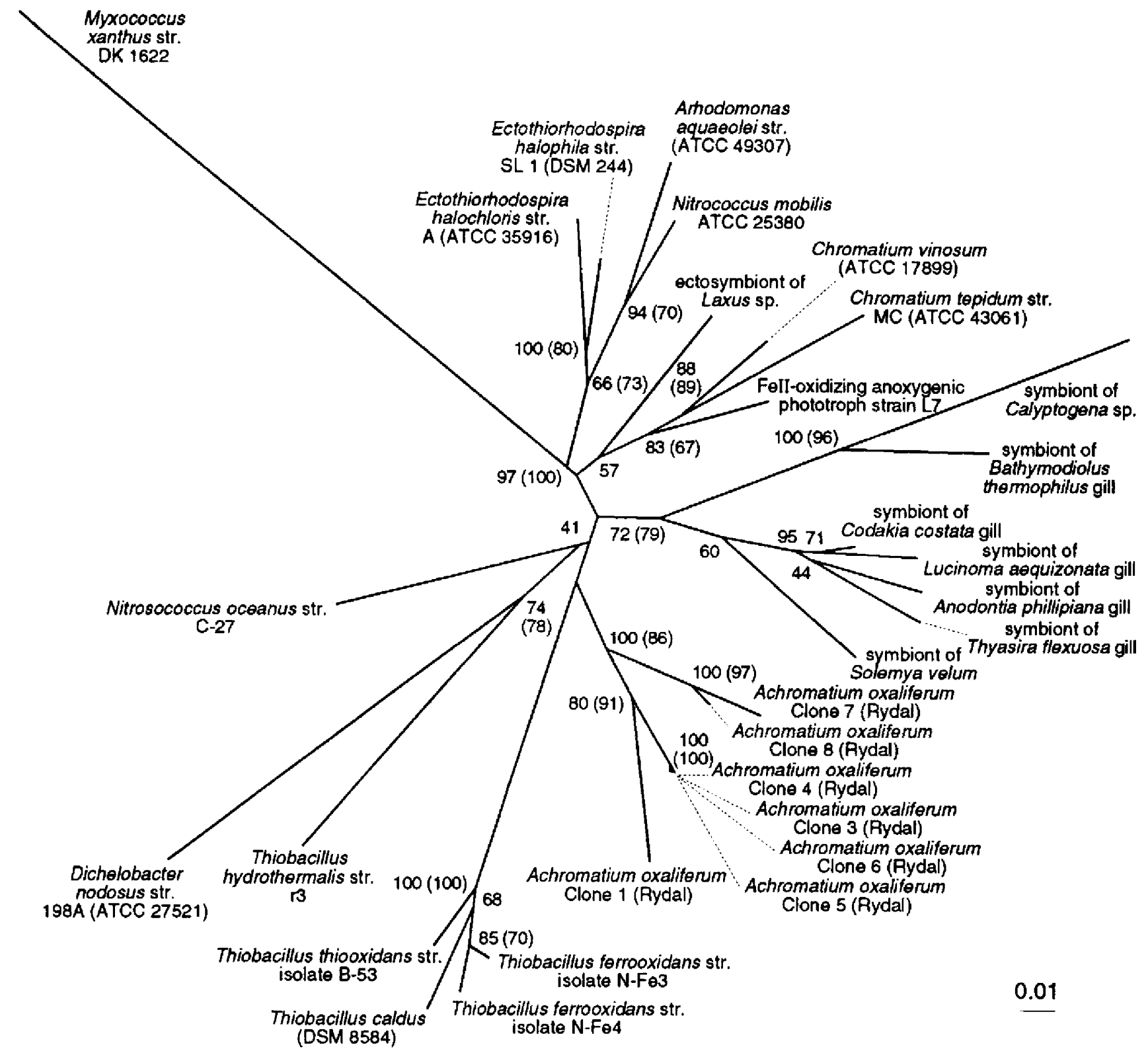

Fig. 6. Distance tree generated from an alignment of 377 positions of $16 \mathrm{~S}$ rRNA sequences from the seven clones sequenced from the $A$. oxaliferum 16S rRNA clone library and representatives of the Chromatium assemblage. Myxococcus xanthus was used as an outgroup. Bootstrap values greater than $40 \%$ are shown at nodes; bootstrap values from distance analyses are shown with values from parsimony analysis in parentheses.

CHECK_CHIMERA program to have homology to the proximal fragment (positions $1-270$ of the clone 5 sequence) also had a similar degree of homology to the distal fragment (positions 271-1489 of the clone 5 sequence). The CHECK_ChImera program is known to have difficulty in identifying chimeric molecules if there is more than $85 \%$ sequence homology between the two parent molecules from which the chimera was derived (Kopczynski et al., 1994). The relatively low similarity of both putative fragments to sequences in the database would not preclude this possibility. It was thus difficult to conclude, from this analysis alone, whether or not the sequence was chimeric. Phylogenetic analyses conducted using the different fragments generated trees with similar topology that were consistent with the phylogeny obtained using the full-length sequence. Further, secondary structure interactions supported the conclusion that the sequence was not a chimera.

Confirmation of $\boldsymbol{A}$. oxaliferum cells as the source of the sequence. To confirm that the sequence obtained had originated from $A$. oxaliferum cells, whole-cell hybridization with fluorescently labelled oligonucleotides was used. Two specific probes were designed based on the 
full-length A. oxaliferum sequence (Aox466 and Aox655). A probe targeted at all Bacteria (Eub338) was used as a positive control and the reverse complement of Eub338 (nonEub) as a negative control to determine the level of non-sequence-specific binding of the oligonucleotide probes (Amann et al., 1990b, Manz et al., 1992). Probe Aox 466 had a low mol $\% \mathrm{G}+\mathrm{C}$ and consequently a low melting temperature $\left(36.6{ }^{\circ} \mathrm{C}\right.$ calculated using the formula

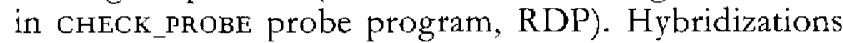
were thus carried out at a low temperature $\left(30^{\circ} \mathrm{C}\right)$. Hybridization at this temperature resulted in high levels of binding of the negative control probe. Hybridization at higher temperatures (e.g. $37^{\circ} \mathrm{C}$ ) prevented binding of the negative control probe (Table 1), but at this temperature Aox466 did not bind either (Table 1). Probe Aox655 was designed with a higher mol $\% \mathrm{G}+\mathrm{C}$ and hybridization with this probe clearly demonstrated that $A$. oxalifertm cells were the source of the $16 \mathrm{~S} \mathrm{rDNA}$ sequence from which it was designed (Fig. 4a, b, Table 1). Pseudomonas putida $\mathrm{PaW} 1$ cells were used as controls to determine the specificity of the Aox655 probe in whole-cell hybridization experiments. The target site of Aox655 in PaW1 has 3 bases different from the $A$. oxaliferum sequence and under stringent hybridization conditions Aox655 bound to A. oxaliferum cells but not $\mathrm{PaW} 1$ cells (Table 1 ).

There was always a low level of non-specific binding of the negative control probe to $A$. axaliferum cells (Fig. $4 \mathrm{c}, \mathrm{d})$. To reduce this it was essential to use a hybridization and wash buffer containing blocking agents such as bovine serum albumin as described by Amann et al. (1990a). If simple Tris-based buffers containing formamide were used (e.g. Manz et al., 1992) the level of nonspecific probe binding was unacceptably high. The presence of calcite within the cells also caused increased levels of non-specific probe binding; thus it was important to ensure that calcite inclusions were removed from the cell during the fixation procedure. This was achieved by fixing the cells in unbuffered paraformaldehyde solution, with a short $\mathrm{HCl}$ treatment to dissolve the calcite.

Comparative sequence analysis. A number of different phylogenetic analyses (distance, parsimony and maximum likelihood) were conducted using the $16 \mathrm{~S} \mathrm{rDNA}$ sequence data. In an analysis of sequences from 98 members of four subdivisions of the Proteobacteria the A. oxaliferum sequences were consistently recovered in the $\gamma$-subdivision of the Proteobacteria (data not shown). This was in agreement with signature nucleotide analysis (Woese, 1987) of the sequence. Of 68 signature nucleotides characteristic of the $\gamma$-Proteobacteria only 6 were different in the A. oxaliferum sequence (clone 5). Two of these differences were associated with a complementary base change across a helix; a further two differences resulted from the absence of corresponding positions in the $A$. oxaliferum sequence due to an unusual secondary structure motif in the V6 region. A. axaliferum was most closely related to the Cbromatium assemblage as defined in the RDP alignment (Maidak et al., 1994). This group of bacteria includes a number of chemolithotrophic Thiobacillus spp., anoxygenic photosynthetic bacteria, and a diverse range of symbiotic sulphur-oxidizing bacteria (Maidak et al., 1994;
Table 2. Identity between seven A. oxaliferum-derived $16 \mathrm{~S}$ rRNA sequences

Data were generated from an alignment of 377 sequence positions. The upper triangle represents percentage identity, the lower triangle the number of differences in the 377 position alignment.

\begin{tabular}{|cccccccc|}
\hline Clone & $\mathbf{1}$ & $\mathbf{3}$ & $\mathbf{4}$ & $\mathbf{5}$ & $\mathbf{6}$ & $\mathbf{7}$ & $\mathbf{8}$ \\
\hline $\mathbf{1}$ & - & $92 \cdot 8$ & $93 \cdot 1$ & $92 \cdot 8$ & $92 \cdot 3$ & $89 \cdot 9$ & $91 \cdot 2$ \\
$\mathbf{3}$ & 27 & - & $99 \cdot 7$ & $99 \cdot 5$ & $98 \cdot 9$ & $91 \cdot 2$ & $92 \cdot 0$ \\
$\mathbf{4}$ & 26 & 1 & - & $99 \cdot 7$ & $99 \cdot 2$ & $91 \cdot 0$ & $91 \cdot 5$ \\
$\mathbf{5}$ & 27 & 2 & 1 & - & $98 \cdot 9$ & $90 \cdot 7$ & $91 \cdot 2$ \\
$\mathbf{6}$ & 29 & 4 & 3 & 4 & - & $90 \cdot 4$ & $91 \cdot 2$ \\
$\mathbf{7}$ & 38 & 33 & 34 & 35 & 36 & - & $97 \cdot 1$ \\
$\mathbf{8}$ & 33 & 30 & 32 & 33 & 33 & 11 & - \\
\hline
\end{tabular}

Lane et al., 1992). More detailed analysis of the nearcomplete $A$. oxaliferum sequence from clone 5 in relation to organisms from the Cbromatium assemblage, using Myxococcus xantbus as an outgroup ( $\delta$-Proteobacteria), revealed that $A$. oxaliferum occupied a deep branching lineage within this group of bacteria (Fig. 5). The low bootstrap values $(20-35 \%)$ indicated that there was no strong relationship with any of the other lineages in the Chromatium assemblage. In different individual analyses, even using the same analysis technique with different sequence positions and subsets of sequences, the $A$. oxaliferum sequence (clone 5) was recovered variously with the endosymbiotic sulphur-oxidizers, Thiobacillus spp. or the anoxygenic photottophs. In all maximum likelihood analyses, using the global rearrangements option and different orders of sequence addition in fastDNAml, the $A$. oxaliferum (clone 5) sequence branched near the root of cither the symbiont or Tbiobacillus ferrooxidans clades but was never recovered with the anoxygenic photottophs. These differences notwithstanding, the topology of the trees obtained were essentially the same; only the placement of the $A$. oxaliferum sequence altered.

\section{Analysis of partial sequences}

When partial sequences ( $377 \mathrm{bp}$ ) from the seven clones were analysed they consistently formed a stable clade with good bootstrap support (Fig. 6). However, the depth of the clade made it difficult to assign the group to any of the recognized lineages within the Cbromatium assemblage and there was low bootstrap support for the clade being associated with any of the known lineages within the Chromatium assemblage (19-27\%).

Three main lineages were evident within the seven cloned $16 \mathrm{~S}$ rRNA gene sequences from A, axaliferum. Within each of these the individual sequences were all very similar (Table 2). For example, there were 1 to 4 differences over 377 bp of sequence from clones 3 to 6 and the sequences were identical even in the highly variable V3 region between positions 440 and 490 (E. coli 


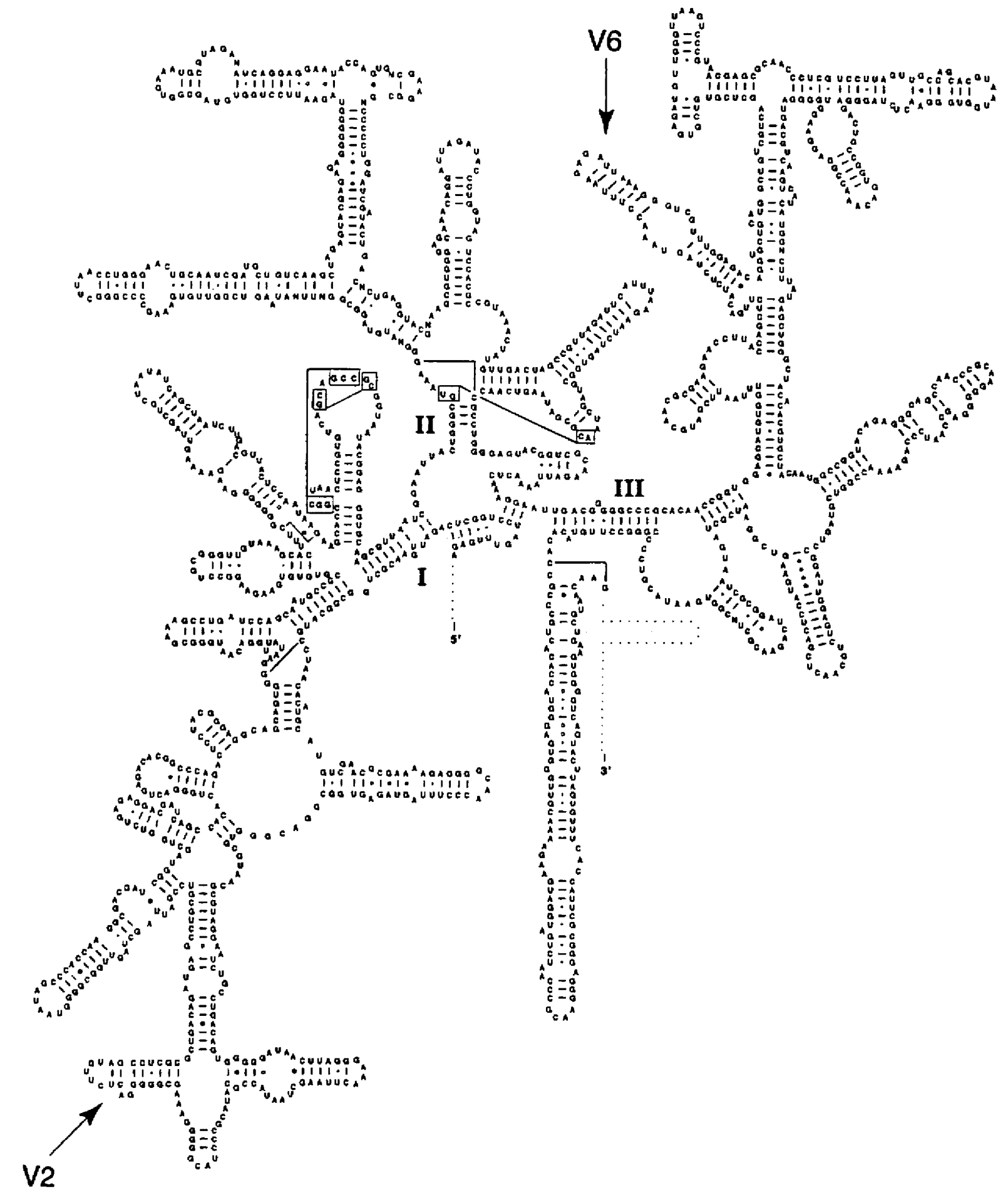

Fig. 7. Secondary structure diagram of $A$, oxaliferum 165 rRNA. Note the pentaloop motif in the $V 2$ region and the novel secondary structure of the $V 6$ region indicated. The secondary structure was generated from 1489 bp of sequence from clone 5 from the $16 \mathrm{~S}$ rRNA gene library of $A$. oxaliferum. The diagram was modified from a PostScript file obtained from the RDP.

numbering). Examination of these sequences with respect to $16 \mathrm{~S}$ rRNA secondary structure indicated that all the differences between clones 3,4 and 5 might be accounted for by sequencing errors or PCR artefacts, as the differences were not associated with complementary changes across helices. Thus, these sequences were essentially identical, but the differences between them and clone 6 were all consistent with the rRNA secondary 
structure. The differences between clone 1 , the clone 7,8 cluster and the clone 5 cluster were, however, much greater (Table 1) and most of them were consistent with the secondary structure model, suggesting that they were unlikely to be due to sequencing or PCR errors.

\section{rRNA secondary structure}

All the sequences obtained were consistent with the currently accepted secondary structure model for bacterial $16 S$ rRNA. There was, however, an unusual secondary structure motif within the V6 region of the rRNA (Fig. 7) (Neefs et al., 1993; Gutell et al., 1985). The sequence of this region was determined independently using three different primers and sequence data consistent with this secondary structure were obtained on every occasion. Similar structures have been noted in Archaea and Eukarya but have not to our knowledge been discovered in the domain Bacteria (Gutell et al., 1985, 1994). A less dramatic difference in secondary structure was the presence of a pentaloop structure at positions 208-211 (E. coli numbering). This feature was present in all clone sequences and therefore is unlikely to represent an artefact.

\section{DISCUSSION}

\section{The biogeochemical significance of $A$. oxaliferum}

The widespread distribution and local abundance of $A$. oxaliferum suggest that it plays an important role in the sediments where it is a major member of the bacterial community. Although there is still no direct, convincing evidence that $A$. oxaliferum is involved in the oxidation of sulphide, using the energy liberated to chemolithotrophically fix carbon dioxide, the data from this study are not inconsistent with this suggestion. The depth distribution profile of $A$. oxaliferum cells in relation to the dissolved oxygen profile confirmed that the bacterium occupied the micro-oxic zone in the sediment, as previously suggested (La Riviere \& Schmidt, 1991). The notion that $A$. oxaliferum may perform a similar role to marine Beggiatoa spp. (Jorgensen, 1982) in oxidizing sulphide on overlapping gradients of sulphide and oxygen (Babenzien, 1991; La Riviere \& Schmidt, 1991) would require that $A$. oxaliferum occupy the micro-oxic zone in a sediment to compete effectively with chemical oxidation. While $A$. oxaliferum does inhabit the micro-oxic zone (Fig. 1) free sulphide was never present at detectable levels in these sediments and it has remained difficult to associate $A$. oxaliferum unequivocally with sulphide oxidation.

Even if a micro-organism is present in high numbers this is no guarantee that it is metabolically active at the time of sampling. However, the intense fluorescence observed in whole-cell hybridization experiments indicated that the A. oxaliferum cells contained high levels of rRNA and were thus likely to be metabolically active.

Analysis of $16 \mathrm{~S}$ rRNA sequences placed A. oxaliferum within the Chromatium assemblage, a group dominated by autotrophic bacteria that oxidize reduced sulphur com- pounds. Although it is impossible to imply physiology from phylogeny alone, the habitat that $A$. oxaliferum occupies is consistent with a role in oxidation of reduced sulphur. This, coupled with the phylogenetic information now available for $A$. oxaliferum, would make it unsurprising if $A$. oxaliferum finally proved to be a sulphuroxidizing lithotroph.

\section{Phylogenetic diversity of $A$. oxaliferum}

Both phenotypic and genotypic data will always be required to fully understand the taxonomy of bacteria (Murray et al., 1990), but in the absence of phenotypic data, phylogenies based on molecular sequences can provide useful information regarding relationships among micro-organisms. The use of comparative $16 \mathrm{~S}$ rRNA analysis in this study has clarified the position of Acbromatium as a genus incertae sedis (La Riviere \& Schmidt, 1989). A. oxaliferum-derived sequences were consistently recovered with the Chromatium assemblage but without strong affiliation with any of the recognized lineages within that group. A. oxaliferum thus represents a novel clade within the $\gamma$-Proteobacteria and is therefore unrelated to the non-fruiting gliding bacteria of the CytophagaFlavobacterium group. A more complete understanding of the taxonomy of the genus Acbromatium will require similar studies on the only other validly described member of the genus, Acbromatium volutans (La Riviere \& Schmidt, 1989). Two lines of evidence suggest that some diversity may exist in the $A$. oxaliferum population from a single site: firstly, the presence of different morphotypes in a single sample, which could simply be an indication of differing physiological state; secondly, and perhaps more compellingly, the recovery of multiple related $16 \mathrm{~S}$ rDNA sequences from a sample of highly purified $A$. oxaliferum cells, suggesting that a number of different $A$. oxaliferum types may have been present in the sediments sampled.

Three main lineages were evident from the phylogenetic analysis (Fig. 6): the first of these was represented by a single sequence (clone 1 ), the second by four sequences (clones 3, 4, 5 and 6) and the third by two sequences (clones 7 and 8). Taking into account possible sequencing and PCR errors and secondary structural constraints, the rRNA sequences of clones 3,4 and 5 were identical and the clone 6 sequence had approximately $99 \%$ identity to clones 3, 4 and 5 . There was approximately $3 \%$ variation between sequences 7 and 8 (Table 2). This degree of variation within the different lineages may represent variability in multiple $\mathrm{rRNA}$ operons, which is known to range from 0.5 to $5 \%$ (Clayton $e$ t al., 1995). The sequence divergence between the three lineages was, however, of the order of $10 \%$ and it would seem unlikely that such a high degree of divergence would be associated with multiple rRNA operons in an ostensibly slow-growing organism. Slow growing organisms as a rule have only one or two rRNA operons, e.g. autotrophic ammoniaoxidizing bacteria ( 1 to 2 ; I. M. Head, unpublished data) and mycobacteria (1; Krawiec \& Riley, 1990). Thus our results suggested two possible conclusions: either that sub-populations of $A$. oxaliferum were present in the 
sediment studied, or that several distinct Achromatium species co-exist in sediments at the Rydal site. At this stage we have insufficient evidence to support the latter conclusion. In addition, Clayton et al. (1995) reported that interstrain differences within a single species can range from 0 to $16 \%$ and concluded that "there is no way to determine whether a $1 \%$ difference between two sequences represents an interoperon, interstrain or interspecific level of divcrgence'. In the case of $A$. oxaliferum, where $16 \mathrm{~S}$ rRNA sequence variability of up to $10 \%$ was observed, the implication is that one cannot confidently determine whether a $10 \%$ difference between sequences represents interstrain or interspecific variation without further evidence.

The original samples obtained were bulk samples of sediment that would not have conserved the stratified structure of the original habitat. Thus cells from different sediment depths, and hence with different environmental conditions, became intermixed. More precise examination of cells from different depths in the sediment may reveal a consistent distribution of morphotypes at different depths. If this were the case it would be necessary to determine whether the differences were due to altered physiological state or to the presence of phylogenetically distinct populations. It will now be possible to test the hypothesis that phylogenetic heterogeneity exists within $A$. oxaliferum and whether morphologically distinct Achromatium species exist in the Rydal sediments. The design of oligonucleotide probes and PCR primers targeting the different sequence types combined with a detailed EM study of the depth distribution of different Acbromatitum morphotypes will allow the exploration of the $A$. oxaliferum population structure at greater resolution. This will also shed light on whether the morphological variation observed corresponds to $r R V A$ sequence variability or the physiological state of individual cells.

\section{ACKNOWLEDGEMENTS}

We thank Dr Sarah Mac Naughton for assistance with cloning PCR products and Bob Liddell of the Lniversity of Newcastle Molecular Biology Facility for running the sequencing reactions. Professor David I loyd and Dr Katy 'Thomas of Cardiff University are thanked for advice regarding MIMS. We are indebted to Dr Martin limbley for cricital reading of the manuscript and are grateful for the support of the IFE and FBA. Financial support from the Society for General Microbiology Research Fund, the Natural [invironmental Research Council (grant GR3/9148) and the 1everhulme Trust is gratefully acknowledged. This research benefited from the use of the SEQNET facility.

\section{REFERENCES}

American Public Health Association (1980). Standard Methods for the Examimation of Water and Wastewater, 15 th edn. Washington, DC: American Public Health Association.

Amann, R. I., Krumholz, L. \& Stahl, D. A. (1990a). Fluorescentoligonucleotide probing of whole cclls for determinative, phylogenetic and environmental studies in microbiology. J Bateriol 172, $762-770$.
Amann, R. I., Binder, B. J., Olson, R. J., Chisolm, S. W., Devereux R. \& Stahl, D. A. (1990b). Combination of $16 \mathrm{~S}$ :R.NA-targeted oligonucleotide probes with tow cytometry for analysing mixed microbial populations. Appi Emiran Mirobiol 56, 1919-1925.

Amann, R. I., Ludwig, W. \& Schleifer, K.-H. (1995). Phylogenetic identification and in situ detection of individual microbial cells without cultivation. Microbiol Ren 59, 143-169.

Babenzien, H.-D. (1991). Acbromatizm oxalferum and its ecological niche. Zentralb/ Mikerobiol 146, 41-49.

Babenzien, H.-D. (1992). Colonization of the sediment--water interface by Achromatium oxaliferum. In Abstracts of the Sixth International Symposium on Microbial Ecology, Barciona, 6-11 September 1992, p. 247.

de Boer, W. E., La Riviere, J. W. M. \& Schmidt, K. (1971). Some properties of Acbromatium oxaliferwm. Antonie Leeanenboek 37, $553-56.3$.

Clayton, R. A.r Sutton, G., Hinkle, P. S., Jr, Bult, C. \& Fields, C. (1995). Intraspecific variation in small-subunit $r R N A$ sequences in GenBank: why single sequences may not adequately tepresent prokaryotic taxa. Int I Syst Bacteriol 45, 595-599.

Edwards, U., Rogall, T., Blöcker, H., Emde, M. \& Bbttger, E. C. (1989). Isolation and direct complete nucleotide determination of entire genes. Characterization of a gene coding for $16 \mathrm{~S}$ ribosomal RNA. Nucleic Acias Res 17, 7843-7853.

Ehrenreich, A. \& Widdel, F. (1994). Anaerobic oxidation of ferrous iron by purple bacteria, a new type of phototrophic metabolism. Appl Entiron Microbiol 60, 4517-4526.

Embley, T. M. (1991). The linear PCR reaction : a simple and robust method for sequencing amplified rRNA genes. Lett Appl Microbini 13, 171174 .

Felsenstein, 1. (1989). PHYLIP-phylogeny inference package. Cladistics 5, 164-166.

Felsenstein, J. (1981). Evolutionary trees from DNA sequences: a maximum likelihood approach. J Mol Evol 17, 368376.

Gicklhorn, J. (1920). Über newe farblose Schwefelbakterien. Zentralbl Bakteriol Parasitente Infektionser Hig 50, 415-427.

Gutell, R. R., Weiser, B., Woese, C. R. \& Noller, H. F. (1985). Comparative anatomy of $16 \mathrm{~S}$-like ribosomal RNA. Prog Nucleic Acid Res Mol Biol 32, 155216 .

Gutell, R. R., Larsen, N. \& Woese, C. R. (1994). I.cssons from an cvolving $r R N A: 16 S$ and $23 S+R N A$ structures from a comparative perspective. Microbiol Rev 58, 10-26.

Head, I. M., Gray, N. D., Pickup, R. W. \& Jones, J. G. (1995). The bingcochomical role of Achromatium oxaliferum. In ()rganic Creochemistry: Deteiopments and Applications to Energy, Climate, Environmeth and Haman History. Selected papers from the 17 th International Meting on Organic Geachemistry, 4th-8th September 1995, Donastia San Sebastian, The Basque Conntry, Spain, pp. 895-898. Editcd by J. (). Grimalt \& C. Dorronsoro. Donostia-San Sebastian : AGOA.

Jones, J. G. (1979). A Graide to Metbods for Estimating Microbial Numbers and Biomass in Freshnater (Freshwater Biological Association Scientific Publication no. 39). Ambleside, LK: Freshwater Biological Association.

Jorgensen, B. B. (1982). Ecology of the hacteria of the sulphur cycle with special reference to anoxic-oxic incriace cnvironments. Phil Trans Roy Sor Lond B 298, 543-561.

Jukes, T. H. \& Cantor, C. R. (1969). Evolution of protein molecules. In Mammalian Protein Metalolism, pp. 21 1.32. Edited by H. N. Munro. New York: Academic Press.

Kopczynski, E. D., Bateson, M. M. \& Ward, D. M. (1994). Recognition of chimeric small-subunit ribosomal DNAs composed of 
genes from uncultivated microorganisms. Appl Environ Microbiol 60, 746-748.

Krawiec, S. \& Riley, M. (1990). Organization of the bacterial chromosome. Mirrobiol Rev 54, 502-539.

La Riviere, J. W. M. \& Schmidt, K. (1989). The Genus Achromatium. In Bergey's Manual of Systematic Bacteriology, vol. 3, pp. 2131-2133. Edited by J. 'T. Staley, M. P. Bryant, N. Pfennig \& J. G. Holt. Baltimote: Williams \& Wilkins.

La Riviere, J. W. M. \& Schmidt, K. (1991). Morphologically conspicuous sulfur-oxidizing Eubacteria. In The Prokaryotes, 2nd edn, pp. 3934-3947. Edited by A. Balows, H. G. Trüper, M. Dworkin, W. Harder \& K. H. Schleifer. New York: Fischer Verlag.

Lane, D. J., Harrison, A. P., Jr, Stahl, D., Pace, B., Giovannoni, S. J., Olsen, G. J. \& Pace, N. R. (1992). Evolutionary relationships among sulphur- and iron-oxidizing eubacteria. Journal of Bacteriology 174, $269-278$.

Lloyd, D., Davies، K. J. P. \& Boddy, L. (1986). Mass spectrometry as an ecological tool for in situ measurement of dissolved gases in sediment systems. FEMS Microbiol Ecol 38, 11-17.

MacNaughton, S. J., O'Donnell, A. G. \& Embley, T. M. (1994). Permeabilization of mycolic acid containing actinomycetes for in situ hybridization with fluorescently labelled oligonucleotide probes. Micrabiology 140, 2859-2865.

Maidak, B. L., Larsen, N., McCaughey, M. J., Overbeek, R., Olsen, G. J., Fogel, K., Blandy, J. \& Woese, C. R. (1994). The Ribosomal Database Project. Nucleic Acids Res 22, 3485-3487.

Manz, W., Amann, R., Ludwig, W., Wagner, M. \& Schleifer, K.-H. (1992). Phylogenetic oligodeoxynucleotide probes for the major subclasses of Proteobacteria: problems and solutions. Syst Appl Microbiol 15, 593-600.

Murray, R. G. E., Brenner, D. J., Colwell, R. R., De Vos, P., Goodfellow, M., Grimont, P. A. D., Pfennig, N., Stackebrandt, E. \& Zavarzin, G. A. (1990). Report of the ad hoc committee on approaches to taxonomy within the Proteobacteria. Int J Syst Bacteriol 40, 213215.

Nadson, G. A. \& Visloukh, S. M. (1923). La structure et la vie de la bactérie géante Acbromatium oxaliferum Schew. Bull Jardin Imp Bot St Pétersbourg, Suppl 122,1-37.
Neefs, J.-M., Van de Peer, Y,, De Rijk, P., Chapelle, S. \& De Wachter, R. (1993). Compilation of small ribosomal subunit RNA structures. Nucleic Acids Res 21, 3025-3049.

Olsen, G. J., Matsuda, H., Hagstrom, R. \& Overbeek, R. (1994). fastDNAml: a tool for construction of phylogenetic trees of DNA sequences using maximum likelihood. Comput Appl Biosci 10, $41-48$.

Pearson, W. R. (1990). Rapid and sensitive sequence comparison with FastP and Fasta. Methods Enzymol 183, 63-98.

Pickup, R. W. (1995). Sampling and detecting bacterial populations in natural environments. In Population Genetics of Bacteria, pp. 295-315. Edited by S. Baumberg, J. P. W. Young, J. R. Saunders \& E. M. H. Wellington. Cambridge: Cambridge University Press. Polz, M. F., Distel, D. L., Zarda, B., Amann, R., Felbeck, H., Ott, J. A. \& Cavanaugh, C. M. (1994). Phylogenetic analysis of a highly specific association between ectosymbiotic, sulfur-oxidizing bacteria and a marine nematode. Appl Environ Micrabiol 60, 4461-4467.

Saitou, N. \& Nei, M. (1987). 'The neighbor joining method: a new method for constructing phylogenetic trees. Mol Biol Evol 4, 406-425.

Schewiakoff, W. (1893). Über einen neten bakterienähnlichen Organismus des Siußwassers. Heidelberg: Habilitationsschrift.

Skuja, H. (1948). Taxonomie des Phytoplanktons einiger Seen in Uppland. Symb Bot Ups 9, 1-399.

Starr, M. P. \& Skerman, V. D. B. (1965). Bacterial diversity: the natural history of selected morphologically unusual bacteria. Annu Rev Microbiol 19, 420-422.

Teske, A., Alm, E., Regan, J. M., Toze, S., Rittmann, B. E. \& Stahl, D. A. (1994). Evolutionary relationships among ammonia- and nitrite-oxidizing bacteria. J Bacteriol 176, 6623-6630.

Ward, D. M., Bateson, M. M., Weller, R. \& Ruff-Roberts, A. L. (1992). Ribosomal RNA analysis of microorganisms as they occur in nature. Adv Microb Ecol 12, 219-286.

Woese, C. R. (1987). Bacterial evolution. Microbiol Rev 51, 221-271.

Received 18 December 1995; revised 18 March 1996; accepted 12 April 1996. 